\title{
ФОРМИ ВЗАЄМОДІЇ НАЦІОНАЛЬНОЇ ПОЛІЦІЇ ТА ЗАСОБІВ МАСОВОЇ ІНФОРМАЦІї
}

\section{THE FORMS OF INTERACTION BETWEEN THE NATIONAL POLICE AND THE MEDIA}

Шнурко Я.В., завідувачка відділення зав'язків із громадськістю Дніпропетровський державний університет внутрішніх справ

Наукова стаття присвячена актуальній для науки адміністративного права темі - формі взаємодії Національної поліції та засобів масової інформації.

У роботі запропоновано визначення: форми взаємодії Національної поліції та ЗМІ - це офіційно визначені правові та організаційні способи узгодження дій між Національною поліцією та ЗМІ з метою реалізації принципу прозорості та відкритості діяльності Національної поліції, підвищення рівня довіри до поліцейських, формування правової свідомості громадян.

Автор виділяє такі особливості форм взаємодії Національної поліції та ЗМІ: основна мета взаємодії поліції та $3 \mathrm{Ml}-$ реалізація принципу прозорості та відкритості діяльності Національної поліції, підвищення рівня довіри до поліцейських, фрормування правової свідомості громадян; діяльність щодо інформування населення здійснюється узгоджено, в тісній співпраці між поліцейськими та представниками 3Ml; 3Ml мають право оприлюднювати публічну інформацію, крім випадків, встановлених законом; взаємодія поліції та ЗмІ відбувається на засадах рівноправного партнерства; одним з обов'язків Національної поліції визначено надання та оприлюднення інформації (крім виключень, встановлених законом); для ефективної взаємодії в складі Національної поліції утворені спеціальні підрозділи, які безпосередньо організовують взаємодію з 3Мl, - підрозділи зав'язків із громадськістю.

Автор поділяє форми взаємодії Національної поліції із ЗМІ на такі види: взаємний інформаційний обмін між Національною поліцією та 3MI; акредитація Національною поліцією журналістів, працівників засобів масової інформації; планування спільних заходів поліції та 3Ml; укладання творчих договорів про співпрацю; надання взаємних консультацій між журналістами та поліцейськими; спільна робота зі зверненнями громадян; підтримка Національної поліції з боку ЗМІ у судових позовах; здійснення громадського контролю за діяльністю Національної поліції з боку ЗМІ.

Зроблено висновок про необхідність розробки та прийняття Наказу МВС України «Про затвердження Концепції вдосконалення взаємодії підрозділів системи МВС України та засобів масової інформації до 2030 року».

Ключові слова: Національна поліція, засоби масової інформації, журналіст, взаємодія, форми, акредитація, інформація, комунікація, творчий договір.

The scientific article is devoted to the topic relevant to the science of administrative law - the forms of interaction between the National Police and the media.

The author proposes a definition: forms of interaction between the National Police and the media are officially defined legal and organizational ways of coordinating actions between the National Police and the media in order to implement the principle of transparency and openness of the National Police, increase trust in police, legal awareness.

The author proposes the features of forms of interaction between the National Police and the media: the main purpose of interaction between the police and the media - the implementation of the principle of transparency and openness of the National Police, increasing trust in police, forming legal awareness; activities to inform the population are coordinated, in the shadow of cooperation between police and media representatives; the media have the right to publish public information, except in cases established by law; interaction between the police and the media takes place on the basis of equal partnership; one of the responsibilities of the National Police is to provide and disclose information (except for exceptions established by law); for effective interaction within the National Police, special units have been established, which directly organize interaction with the media - public relations units.

The author divides the forms of interaction of the National Police with the media into the following types: mutual information exchange between the National Police and the media; accreditation by the National Police of journalists and media workers; planning joint police and media events; concluding creative agreements on cooperation; providing mutual consultations between journalists and police; joint work with citizens' appeals; support of the National Police by the media in lawsuits; exercising public control over the activities of the National Police by the media.

The conclusion is made about the need to develop and adopt the Order of the Ministry of Internal Affairs of Ukraine "About approval of the Concept of improving the interaction of units of the Ministry of Internal Affairs of Ukraine and the media until 2030".

Key words: National police, mass media, journalist, interaction, forms, accreditation, information, communication, creative contract.

Актуальність теми. Процес трансформування правоохоронних органів України, у тому числі Національної поліції, відбувається не так стрімко та ефективно, як було проголошено на початку реформування системи МВС України у 2014 році. Фактично становлення правової основи діяльності поліції, формування структури іiі органів та підрозділів, визначення та розподіл компетенції між органами та підрозділами поліції, подолання проявів злочинності, запровадження механізмів підвищення ефективності діяльності поліцейських, забезпечення прав та свобод людини та громадянина та інші напрями вдосконалення діяльності Національної поліції України продовжують реалізовуватися дотепер.

Початок реформи МВC України характеризується піком неспроможності міліції України забезпечити законними засобами публічну безпеку та охорону прав особи, що знаходило відповідне відображення в засобах масової інформації (далі - ЗМІ). Керівництво МВС України недооцінювало роль мас-медіа, а комунікативні відносини між міліцією та 3МІ помітно деформувалися. I, навпаки, ми спостерігали повну підтримку ЗМІ під час реалізації положень реформи МВС України, які формували позитивний імідж оновленого поліцейського (зокрема патрульного поліцейського). Тобто вкрай важливою видається роль 3МI у формуванні думки громадськості про діяльність поліції, тобто іміджу поліцейського.

Викладене свідчить про важливість теми цієї роботи, актуалізує пошук нових форм взаємодії поліції та 3МI, що дало б змогу адекватно формувати громадську думку як на користь усього суспільства, так і Національної поліції.

Постановка проблеми. Якісне та кількісне зростання потужності інтелектуального та духовного впливу сучасних 3MI та комп'ютерних технологій призводить до появи нового комунікативного феномена, віртуалізації суспільних відносин. Зазначене дає змогу констатувати перехід взаємовідносин поліцейських та 3МІ на новий рівень із застосуванням оновлених форм взаємодії та потребу їх наукового дослідження та подальшого вдосконалення.

Стан дослідження проблеми. Безпосередньо у своїх роботах форми взаємодії поліції (міліції, органів внутрішніх справ) та 3МІ в адміністративно-правовому аспекті досліджували М. Андрійчук, Т. Андрійчук, В. Булаєв, 
В. Литвин, Ю. Луканов, С. Недов, Л. Опришко, С. Томіленко, I. Шашкін та багато інших. Водночас розвиток сучасних технологій, перехід у віртуальну реальність більшості суспільних відносин вимагає від державних органів (зокрема Національної поліції) пошуку нових форм взаємодії зі ЗМІ з урахуванням набутого історичного досвіду.

Мета наукової статті - на підставі аналізу законодавства України, здобутків вітчизняних вчених, практичної діяльності Національної поліції та ЗМІ визначити та охарактеризувати види форм їх взаємодії. Для досягнення поставленої мети нами поставлені такі завдання: запропонувати поняття «форми взаємодії Національної поліції та 3МІ», виокремити види форм взаємодії Національної поліції та 3MI, а також охарактеризувати їх.

Виклад основного матеріалу. Задля розуміння сутності поняття «форми взаємодії Національної поліції та 3МІ» дослідимо це поняття детальніше.

Згідно з тлумачним словником, форма - це тип, будова, спосіб організації чого-небудь; зовнішній вияв якогонебудь явища, пов'язаний із його сутністю, змістом [1]; взаємодія - це взаємний зв'язок між предметами в дії, а також погоджена дія між ким-, чим-небудь [2]. Виходячи з етимології словосполучення, можна констатувати, що форми взаємодії - це способи, за допомогою яких відбувається погоджена між двома і більше суб'єктами діяльність.

Водночас у вітчизняній науці немає одностайного підходу до розуміння категорії «форми взаємодії», але провідною все ж таки залишається думка про ототожнення понять «форма» та «спосіб» у контексті взаємодії поліції з іншими державними органами, органами місцевого самоврядування та громадськістю.

Аналіз нормативно-правових актів та діяльності Національної поліції дає змогу зробити висновок про наявність таких характерних рис взаємодії Національної поліції та 3MI:

- основна мета взаємодії поліції та ЗМІ - реалізація принципу прозорості та відкритості діяльності Національної поліції, підвищення рівня довіри до поліцейських, формування правової свідомості громадян;

- діяльність щодо інформування населення здійснюється узгоджено, в тісній співпраці між поліцейськими та представниками 3МI;

- ЗМІ мають право оприлюднювати публічну інформацію, крім випадків, встановлених законом;

- взаємодія поліції та ЗМІ відбувається на засадах рівноправного партнерства;

- одним з обов'язків Національної поліції визначено надання та оприлюднення інформації (крім виключень, встановлених законом);

- для ефективної взаємодії в складі Національної поліції утворені спеціальні підрозділи, які безпосередньо організовують взаємодію з 3MI, - підрозділи зв'язків із громадськістю.

На підставі виділених особливостей пропонуємо під формами взаємодії Національної поліції та ЗМІ розуміти офіційно визначені правові та організаційні способи узгодження дій між Національною поліцією та ЗМІ з метою реалізації принципу прозорості та відкритості діяльності Національної поліції, підвищення рівня довіри до поліцейських, формування правової свідомості громадян.

Визначення форм взаємодії поліції та ЗМІ зазвичай відбувається на підставі аналізу нормативно-правових актів та практичної діяльності поліцейських. Чіткого визначення видів форм взаємодії означених суб'єктів у нормативно-правових актах не відбулося, а однозначної думки науковців із приводу видів зазначених форм не існує.

Так, у своєму дисертаційному дослідженні С. Недов формами взаємодії органів та підрозділів внутрішніх справ із ЗМІ визнає: 1) проведення брифінгів (пресконференцій); 2) висвітлення виступів працівників органів внутрішніх справ; 3) формування громадської думки;
4) підготовку інформаційних матеріалів (заміток, звітів, репортажів); 5) підготовку та розміщення в засобах масової інформації соціальної реклами правоохоронної діяльності ОВС; 6) підготовку прес-релізу; 7) проведення інтерв'ю; 8) проведення сеансів телефонного зв'язку «гаряча лінія»; 9) проведення засідань «круглого столу»; 10) реагування на виступи у ЗМI 3 проблемних питань діяльності органів внутрішніх справ; 11) розгляд звернень (запитів) від засобів масової інформації; 12) проведення консультацій [3, с. 15].

Такий підхід висвітлює доволі детальний огляд видів форм взаємодії, проте не позбавлений недоліків, пов'язаних із втратою актуальності, оскільки внесення змін до законодавчих актів спонукало до запровадження нових форм взаємодії (наприклад, поза увагою науковця залишилася акредитація журналістів поліцією). Відповідно, можна констатувати змінюваність форм взаємодії Національної поліції та ЗМІ залежно від зовнішніх обставин.

Більш сучасним та узагальненим підходом вирізняється наукова робота, представлена В. Литвином, в якій виділені такі форми взаємодії поліцейських та представників 3МI: надання журналістам інформації щодо діяльності органів Національної поліції, акредитація журналістів при Національній поліції України; укладання творчих договорів про співпрацю; спільне планування виступів у ЗМІ; проведення спільних благодійних акцій, випусків рубрик і теле- та радіопрограм; проведення «прямих ліній», «прямих ефірів» та «круглих столів»; організація роботи телефонів довіри, вивчення отриманої кореспонденції, відгуків на виступи ЗМІ та підтримка в судових позовах [4, с. 95].

На наш погляд, деякі запропоновані положення є дискусійними. Наприклад, ми наголошуємо на партнерських відносинах між Національною поліцією та 3MI, а тому однобічне інформування 3МІ з боку Національної поліції видається неповним. Так, ст. 9 Закону України «Про Національну поліцію» визначає необхідність інформування громадськості про результати своєї діяльності у сфері забезпечення прав і свобод особи, публічного порядку та безпеки, протидії злочинним проявам [5]. Проте 3МI $€$ водночас суб'єктами, які уповноважені подавати звернення до органів та підрозділів Національної поліції, в тому числі про вчинені кримінальні правопорушення та інші події. Тобто ЗМІ також надають інформацію поліцейським, а тому інформування між Національною поліцією та ЗМІ є взаємним. Саме тому, на наш погляд, першою формою взаємодії Національної поліції та ЗMI має бути взаємне інформування Національної поліції та 3МI, або інформаційний обмін між поліцією та 3МІ.

Також варто наголосити на тому, що стрімкий розвиток віртуалізації соціальної реальності дозволяє вважати іiї не просто побічним продуктом технологічних та соціокультурних змін, а самостійним виміром, специфічною умовою комунікативної взаємодії інститутів у XXI столітті. У цьому особливу роль відіграє діяльність сучасних засобів.

Серед них варто виділити насамперед протиріччя між потребою суспільства в об'єктивній інформації про результати правоохоронної діяльності та реальною практикою інформування, між прийомами прямолінійної відомчої пропаганди та вимогами, що висуваються ринково інституалізованими ЗМІ до партнерської взаємодії комунікаторів, використання сучасних комунікативних технологій у формі паблік рілейшенз та реклами, між символізацією образу поліції як силової, військової, репресивної організації та соціально орієнтованими очікуваннями громадськості щодо поліції, покликаної вирішувати соціально-правові проблеми територіальних громад, забезпечувати допомогу та правовий захист особи.

Тобто, на зміну традиційному формату інформаційного обміну між поліцейськими та 3МІ (газети, журнали, телепрограми, тощо) приходить сучасний, технологічний 
формат. Ведення сторінок у соціальних мережах, офіційних вебсайтів від імені органів та підрозділів Національної поліції стало нормою для сучасного українського суспільства. Такі сторінки, сайти є фактично реалізацією принципу відкритості та прозорості діяльності Національної поліції, адже через них відбувається інформування населення про діяльність, а також існує можливість налагодження зворотного зв'язку з громадою (коментарі, відмітка у постах або сторіз відповідної сторінки поліцейського підрозділу). Зазвичай саме підрозділи зв'язків із громадськістю Національної поліції ведуть такі сторінки та сайти, а також здійснюють моніторинг мережі Інтернет на предмет виявлення та попередження фактів, що дискримінують імідж поліцейського. Під час аналізу інформації в Інтернет-мережі представники підрозділів зав'язків із громадськістю можуть визначити актуальні для спільноти теми з метою їх висвітлення в контексті ефективної діяльності поліції, опосередковано впливаючи на свідомість громадян, формуючи позитивний імідж поліцейського, сприяючи підвищенню рівня довіри до поліцейських.

Прийняття електронних звернень також $є$ одним із сучасних елементів діяльності поліції. Спілкування з представниками 3МІ через електронне листування, прийняття від ЗМІ електронних звернень та запитів - все це оновлює підхід до розуміння взаємодії поліції та ЗМІ. Позитивними при цьому є оперативність (електронні листи на відміну від паперових надходять майже негайно), ефективність (можливість направити великі обсяги інформації,, стиснувши іiі), безпека (наприклад, особливо в умовах запровадження карантину, коли зайві контакти між людьми загрожують захворюванням) обміну інформацією.

Крім того, не новим форматом є спілкування 3 громадою через групи в месенджерах, телеграм-канали, які так само, як і соціальні мережі, сприяють інформатизації населення, правовій освіті громадян. Вважаємо за доцільне покласти функцію ведення таких груп у месенджерах та телеграм-каналах на підрозділи зав'язків із громадськістю Національної поліції.

Згадані вже іншими науковцями такі форми взаємодії Національної поліції та 3МІ, як проведення прямих ефірів, круглих столів, гарячих ліній, тощо з представниками Національної поліції, потребують також оновлення та технологізації процесу. Саме тому використання електронних сервісів для проведення відеоконференцій (наприклад, Zoom) є ефективним та сучасним способом взаємодії Національної поліції зі 3МI.

Кардинально іншим є підхід науковців, за якого форми взаємодії влади з громадськістю поділяються на інформування, консультування, партнерство, делегування, контроль [6]. Застосувавши такий підхід до сфери взаємодії Національної поліції та 3МI, можемо підтвердити його актуальність та можливість реалізації на практиці.

Як вже зазначалося, інформування здійснюється через проведення прес-конференцій, круглих столів, теле-, радіопередач, видання буклетів, прес-релізів, ведення офіційних сторінок у соціальних мережах, груп у месенджерах, телеграм-каналах, офіційних сайтів органів і підрозділів поліції та інше.
Консультування відбувається шляхом залучення поліцейських до проєктів 3MI, проведення опитування громадської думки з приводу діяльності Національної поліції, зокрема щодо визначення рівня довіри населення до поліцейських, проведення громадських слухань із питань правоохоронної діяльності.

Партнерство між Національною поліцією та 3МІ відбувається шляхом укладання контрактів, домовленостей про спільну роботу у визначених напрямках. Партнерство також визначається відносинами, які характеризуються координацією спільної діяльності поліцейських та представників засобів масової інформації, відсутністю домінуючого суб'єкта.

Делегування передбачає часткову передачу повноважень від одного суб'єкта іншому, що ми можемо спостерігати під час заснування у складі Національної поліції підрозділів зв’язків із громадськістю.

Громадський контроль - це невід'ємна частина діяльності Національної поліції. I саме ЗМІ є однією з тих рушійних сил, які спонукають поліцейських до правомірного виконання повноважень із дотриманням принципів верховенства права, законності, дотримання прав та свобод осіб та інших. На підтвердження сказаного можна згадати численні відеоролики, на яких задокументовані професійні та непрофесійні дії поліцейських, що формують відповідне ставлення до поліції в державі також. Тобто громадський контроль - це також основна форма взаємодії Національної поліції із ЗМI.

Зважаючи на сказане, можемо запропонувати поділити форми взаємодії Національної поліції із ЗМІ на такі види: взаємний інформаційний обмін між Національною поліцією та 3MI; акредитація Національною поліцією журналістів, працівників засобів масової інформації згідно 3 вимогами Закону України «Про інформацію»[7]; планування спільних заходів поліції та 3МІ; укладання творчих договорів про співпрацю; надання взаємних консультацій між журналістами та поліцейськими; спільна робота зі зверненнями громадян; підтримка Національної поліції з боку 3МI у судових позовах; здійснення громадського контролю за діяльністю Національної поліції з боку 3МІ

Висновки. 3 огляду на викладене видається актуальним визначення форм взаємодії Національної поліції та 3МI на відомчому нормативно-правовому рівні. Пропонуємо розробити Концепцію вдосконалення взаємодії підрозділів системи МВС України та засобів масової інформації до 2030 року та затвердити це Наказом МВС України. Концепція має бути орієнтована на вжиття заходів організаційноправового та науково-методичного характеру, спрямованих на вироблення ефективних підходів до організації прямого та зворотного інформаційного зв'язку з суспільством, що сприяють максимальному використанню можливостей 3МI на користь оперативно-службової діяльності поліції.

Окреслений напрям наукового дослідження вважаємо перспективним, оскільки спостерігається підвищення ролі громадського контролю в діяльності Національної поліції та вимога розширення меж принципу відкритості та прозорості діяльності Національної поліції в демократичному суспільстві. Надалі варто наголосити на напрямах діяльності Національної поліції у сфері взаємодії зі 3МІ, принципах та інших загальних засадах такої взаємодії.

\section{ЛITEPATYPA}

1. Словник української мови: в 11 томах. 1979. Т. 10. С. 617. URL: http://sum.in.ua/s/forma

2. Словник української мови: в 11 томах. 1970. T. 1. С. 346. URL: http://sum.in.ua/s/vzajemodija

3. Недов С.Л. Організаційно-правові засади взаємодії органів внутрішніх справ із засобами масової інсормації : автореф. дис. ... канд. юр. наук : 12.00.07 «Адміністративне право і процес; фрінансове право; інформаційне право». Харків, 2009. 19 с.

4. Литвин В.В. Комунікація поліцейського патрульної поліції зі ЗМІ. Юридична психологія. 2019. № 2 (25). С. 93-99. doi: https://doi.org/10.33270/03192502.93

5. Про Національну поліцію : Закон України від 02.07 .2015 р. № 580-VIII. Відомості Верховної Ради України. 2015. № 40-41. Ст. 379.

6. Уряд для громадян. Ініціативи щодо поліпшення якості послуг. Український переклад. Львів : Львівск. фріліал УАДУ, 2000. 293 с.

7. Про інформацію : Закону України від 02.10.1992 р. № 2657-XII. URL: https://zakon.rada.gov.ua/laws/show/2657-12. 